$\mathrm{DE}$

M E D I C I N A

T R O P I C A L

$\mathrm{DE}$

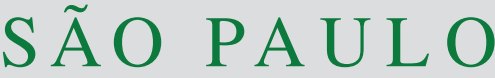

JOURNAL OF THE SÃO PAULO INSTITUTE OF TROPICAL MEDICINE

'Universidade Federal do Maranhão, Centro de Ciências Biológicas e da Saúde, Departamento de Biologia, Núcleo de Imunologia Básica e Aplicada, São Luís, Maranhão, Brazil

${ }^{2}$ Universidade Federal de Minas Gerais, Instituto de Ciências Biológicas, Departamento de Parasitologia, Laboratório de Fisiologia de Insetos Hematófagos, Horizonte, Minas Gerais, Brazil

Correspondence to: Adalberto Alves Pereira Filho

Universidade Federal de Minas Gerais, Instituto de Ciências Biológicas,

Departamento de Parasitologia, Laboratório de Fisiologia de Insetos Hematófagos, Av. Antônio Carlos, 6627, CEP 31270-901, Belo Horizonte, MG, Brazil

Tel: +553134092850

E-mail: magneto_pa@ hotmail.com

Received: 05 September 2017

Accepted: 01 December 2017

\section{Evaluation of molluscicidal activity of three mangrove species (Avicennia schaueriana, Laguncularia racemosa and Rhizophora mangle) and their effects on the bioactivity of Biomphalaria glabrata Say, 1818}

Renato Juvino de Aragão Mendes ${ }^{1}$, Adalberto Alves Pereira Filho², Aline de Jesus Lustosa Nogueira', Karla Regina Freitas Araújo, Clícia Rosane Costa França1, Iramar Borba de Carvalho', Natale Maria Lindoso da Silva1, Alexandre Santana Azevedo', Ivone Garros Rosa'

\section{ABSTRACT}

Schistosomiasis is a disease of global extent reaching populations in social vulnerability. One of the control measures of this parasitosis is the use of molluscicidal substances that can fight snails of the genus Biomphalaria, intermediate hosts of Schistosoma mansoni. The aim of this work was to study the toxic activity of three mangrove species (Avicennia schaueriana Stapf. \& Leech, ex Moldenke, 1939, Laguncularia racemosa (L.) CF Gaertn, 1807 and Rhizophora mangle L. 1753) on the biological activities of snails Biomphalaria glabrata. Hydroalcoholic extracts were prepared from the stem and leaves of each of the three plant species to which mollusks were exposed. The phytochemical analysis of plants showed the presence of important metabolites in the leaves and stems of L. racemosa and $R$. mangle, such as tannins and saponins, but the absence of these metabolites in A. schaueriana. Leaf and stem extracts of the three plant species showed low molluscicidal activity, not reaching the standards determined by the World Health Organization (WHO, 1983). L. racemosa and $R$. mangle has interfered with motility, feeding and oviposition of snails, unlike the extracts of A. schaueriana, which had no effect on these activities.

KEYWORDS: Schistosomiasis. Snails. Biomphalaria glabrata. Mangrove. Molluscicide.

\section{INTRODUCTION}

Schistosomiasis, caused by parasites of the genus Schistosoma, is a highly relevant disease in the global health setting, reaching predominantly poorer populations living in rural areas or in urban slums. It presents as a chronic disease of great epidemiological relevance as much by its prevalence as by the severity of clinical complications, constituting an important source of morbidity and mortality mainly in developing countries ${ }^{1,2}$. At least 249 million people need treatment every year ${ }^{3}$. In Brazil, considered the country with the largest endemic area in the Americas, about 25 million people are at risk of contracting the disease. Endemic and focal areas are found in 19 States located in all regions of the country ${ }^{4}$.

In Brazil, Schistosoma mansoni shows a life cycle involving mollusks Biomphalaria spp., which act as intermediate hosts while humans are definitive hosts. However, it has been shown that wild rodents with semi-aquatic habits are capable to establish a productive infection of this parasite ${ }^{5}$. In addition, they are also likely to spread the disease in endemic areas ${ }^{5}$. Among the three species of Biomphalaria 
spp. registered in Brazil, Biomphalaria glabrata is the one that has the largest geographic distribution and is more adapted to the transmission cycle . $^{6}$

\section{Disease control}

In order to contain the spread of this disease, over the years, the World Health Organization (WHO) has established successive guidelines for the evaluation and control of the endemic disease on a global scale, resulting in an approach called 'integrated control', which covers the chemotherapeutic treatment, implantation of infrastructure and basic sanitation in focal areas, development of informative and educational campaigns, development of a vaccine and use of molluscicidal products to fight against the snail vector of the disease, as an auxiliary measure ${ }^{6}$.

Niclosamide (Bayluscid ${ }^{\circledR}$ ) is the most indicated molluscicide by WHO. This compound affects a wide variety of mollusks, cestodes and cercariae, and is also used as an antiparasitic in human and veterinary medicine. Niclosamide has very low toxicity to mammals (WHO Hazard Class III), but has the disadvantage of being toxic to aquatic vertebrates (fish and amphibians) and crustaceans ${ }^{7}$, besides having a high cost and yet being difficult to operationalize ${ }^{8}$.

\section{Natural molluscicides}

As an alternative to Niclosamide, viability of use of plant origin products with molluscicidal effect is studied. Some plants have already had these specific effects proven, such as Sapindus saponaria, Swartzia madagascariensis, and Balanites aegyptiaca, reported by Mccullough et al. ${ }^{9}$, along with other 36 species, according to a review showing the molluscicidal activity of plant parts against several species of snails, such as B. glabrata, Lymnaea acuminata, Bulinus truncatus and others ${ }^{10}$. In Brazil, studies with Euphorbia milii var. splendens (Bojer ex Hook.) Ursch \& Leandri 1955 (Christ thorn) showed that not only they have proven molluscicidal activity ${ }^{11}$, but they also do not have cytological action when concentrations are limited to $200 \mathrm{ppm}^{12}$.

Secondary metabolites (tannins, saponins, alkaloids, etc.) are biosynthesized by plants for different purposes, such as growth regulation, intra and interspecific interactions, protection against ultraviolet radiation and defense against predators and infections ${ }^{13}$. Many of the secondary metabolites present important biological and pharmacological activities and are used as chemotherapeutic agents, or serve as a starting points for development of new drugs ${ }^{14}$. The phytochemical analysis is aimed to evaluate the quantity and quality of the chemical constituents (secondary metabolites) of plant species. In case there is no research available on a species of interest, a preliminary phytochemical analysis may indicate the groups of relevant secondary metabolites present on the species ${ }^{15}$.

In studies on plants with molluscicidal activity, two important secondary metabolites are mainly sought: saponins and tannins, which are believed to be the main toxic substances to mollusks. The effect of tannins is unclear in this process, but it is believed that they are able to complex with digest enzymes and proteins ${ }^{16,17}$ and, finally, they can turn into toxic products in the digestive tract after hydrolysis ${ }^{18}$.

The State of Maranhão has the second largest mangrove strip in Brazil. This ecosystem presents a huge importance to the State both, in the biological and economic sense. The mangrove has plant species known to be rich in tannins ${ }^{19}$. There are three predominant plant species in this ecosystem: Avicennia schaueriana, Laguncularia racemosa and Rhizophora mangle. The proximity of this ecosystem to endemic areas of schistosomiasis justifies the investigation of these plant species and the eventual exploration of their compounds, thus this work is aimed at studying the effects of hydroalcoholic extracts of leaves and stems of three mangrove species on the bioactivity of Biomphalaria glabrata.

\section{MATERIALS AND METHODS}

\section{Collection and identification of plant material}

Plants were collected in an estuary located in a mangrove at Araçagi beach, at a point located between the coordinates $2^{\circ} 45^{\prime} 74.07^{\prime \prime}$ South latitude and $44^{\circ} 16^{\prime} 59.87^{\prime \prime}$ West longitude, in the municipality of Raposa, located on São Luís Island, in the State of Maranhão (MA), Brazil. The leaves and stems of the species Avicennia schaueriana, Laguncularia racemosa and Rhizophora mangle were obtained during the dry season, between 06:00 and 07:00 in the morning. Specimens were transported to the Nucleus of Basic and Applied Immunology (NIBA) Federal University of Maranhão - Bacanga Campus. Then, exsiccates were prepared and deposited in the Herbarium of Maranhão - MAR, catalogued under the registration numbers $7.484 ; 7,485$ and 7,486, respectively.

\section{Preparation of extracts and dry residues}

The crude extract was prepared from $500 \mathrm{~g}$ of leaves and stems of the three plant species, which were ground in an industrial blender and the resulting material was 
placed in a beaker, to which were added $2000 \mathrm{~mL}$ of $92 \%$ ethanol, in a ratio of 1: $4(\mathrm{~g} / \mathrm{mL})$. The material remained under maceration for 15 days. The macerate was filtered in filter paper and the resulting was placed in a glass container. Then, $80 \mathrm{~mL}$ of the hydroalcoholic extractwere evaporated in water bath at $100^{\circ} \mathrm{C}$ until the crude residue was obtained.

\section{Phytochemical profile}

Phytochemical analyses of the three species were performed based on methodologies described by Matos ${ }^{20}$ and referenced by Pereira-Filho $\mathrm{et} \mathrm{al.} .^{21}$, using the following tests: identification of tannins, alkaloids, coumarins, steroids and triterpenoids and saponins. Concentrations of the compounds are described using crosses, where $(+++)$ means strongly positive, $(++)$ moderately positive, $(+)$ weakly positive, (-) traces and (0) undetected.

\section{Obtainment, maintenance and snail screening}

Snails Biomphalaria glabrata were collected in a neighborhood on the outskirts of the city of São Luís, MA, and kept in the NIBA bioterium, in aquariums containing dechlorinated water and fed with lettuce every two days. The mollusks identification was achieved following the methodology described by the Ministry of Health ${ }^{22}$ Snails under study were weekly analyzed for one month to record their positivity to $S$. mansoni. In the analysis, they were placed individually in glass vials, with $5 \mathrm{~mL}$ of dechlorinated water and exposed to the light of two $60 \mathrm{~W}$ lamps, for $1 \mathrm{~h}$. Afterwards, they were examined under a stereoscopic magnifying glass ZEISS, to verify the elimination of cercariae in water. Only healthy snails with shells of 10-18 $\mathrm{mm}$ in diameter were selected for molluscicidal tests ${ }^{23}$.

\section{Evaluation of molluscicidal activity}

Molluscicidal activity was evaluated according to the procedure recommended by $\mathrm{WHO}^{24}$. Solutions of the crude plant extract obtained from each part (stem and leaf) of the three plants were prepared, totaling 6 extracts, each one prepared in three different concentrations: 20,60 and $100 \mathrm{ppm}$. For each concentration, five snails were used, with three repetitions. Mollusks were exposed to solutions for $24 \mathrm{~h}$ at room temperature. After that time, they were removed and washed twice with dechlorinated water, then mollusks were fed with lettuce and observed every $24 \mathrm{~h}$ for 2 days ( $48 \mathrm{~h}$ ) to evaluate mortality, motility, oviposition and feeding. As controls, the same number of snails immersed in $500 \mathrm{~mL}$ of dechlorinated water was used. The following criteria were adopted to verify the death of the snails: discoloration of shells, immobility, exposure of the visceral mass and hemolymph release.

\section{Evaluation of snails bioactivity}

Motility of the animals was analyzed by observing the locomotion of specimens in the pots. It was also verified whether they presented expansion or contraction behavior of the cephalopodal mass. For the evaluation of each extract effect on the animals oviposition, counting of released eggs was performed $72 \mathrm{~h}$ after the exposure using a ZEISS ${ }^{\circledR}$ stereoscopic magnifying glass. To evaluate the feeding capacity, snails were provided with $5 \mathrm{~g}$ of lettuce (Lactuca sativa $\mathrm{L}$.) in each of the three flasks, of each concentration, every $24 \mathrm{~h}$ after the exposure, until $72 \mathrm{~h}$. To avoid lettuce degradation, the amount of lettuce was measured every $24 \mathrm{~h}$ and the same amount was renewed and old lettuce was withdrawn.

\section{Statistical analysis}

Statistical analyses of this study were carried out with Statistica 7.0 (StatSoft) and SPSS v. 19 (IBM), adopting a significance level of $5 \%$. Tests performed to evaluate results were ANOVA factorial for evaluation of food capacity, oviposition and feeding; Qui-square and chi-square with Yates correction were used for the evaluation of mollusks mortality and motility.

\section{RESULTS}

\section{Phytochemical analysis}

Phytochemical analyses showed that the three species presented variations both in the presence/absence of secondary metabolites and in their quantity, as shown in Table 1.

Among the analyzed metabolites, the plant that presented the greatest variety of secondary metabolites was $R$. mangle. Many of these metabolites were absent in A. schaueriana. The species $L$. racemosa had the highest intensity of metabolites in stem and leaves.

$R$. mangle was the species with the highest concentration of tannins, found in great intensity both in leaves and stems (+++), followed by L. racemosa, which had the highest concentration in stems $(++)$ when compared to leaves $(+)$. The tannin test did not detect the presence of traces of this metabolite in A. schaueriana species.

The test for saponins showed that $L$. racemosa was the plant with the highest concentration among the three 
Table 1 - Presence of secondary metabolites found in the hydroalcoholic extracts of stems and leaves of Avicennia schaueriana, Laguncularia racemosa and Rhizophora mangle

\begin{tabular}{lcccccc}
\hline Secondary & \multicolumn{2}{c}{ Avicennia schaueriana } & \multicolumn{2}{c}{ Laguncularia racemosa } & \multicolumn{2}{c}{ Rhizophora mangle } \\
\cline { 2 - 6 } metabolites & Stem & Leaves & Stem & Leaves & Stem & Leaves \\
\hline Tannins & 0 & 0 & ++ & + & +++ & + \\
Saponins & 0 & 0 & + & ++ & + & + \\
Alkaloids & 0 & 0 & 0 & 0 & + & + \\
Triterpenoids & 0 & 0 & +++ & ++ & + & + \\
Steroids & +++ & ++ & 0 & + & + \\
Coumarins & + & +++ & + & +
\end{tabular}

$(+++)=$ Strongly positive; $(++)=$ Moderaly positive; $(+)=$ Weakly positive; $(-)=$ Traces; $0=$ undetected $^{14}$.

species, with moderate intensity in leaves $(++)$ and low in stems (+). Leaves of $R$. mangle also presented low intensity (+) of saponins, and only traces (-) in stems. In A. schaueriana species no traces of saponins were found.

Alkaloids were detected only in stems of $L$. racemosa $(+++)$ and weakly positive in stems of $R$. mangle $(+)$. Triterpenoids were only detected in stems of $R$. mangle $(+)$. Steroids were found in different concentrations in all plants, being strongly positive $(+++)$ in stems and moderately positive (++) in leaves of A. schaueriana and L. racemosa, and weakly positive (+) in leaves and stems of $R$. mangle. Coumarins were detected in high intensity $(+++)$ in leaves of A. schaueriana and in low intensity (+) in leaves and stems of other species. The presence of this metabolite in L. racemosa stems was not detected.

\section{Evaluation of the bioactivity of snails in relation to extracts}

Considering the motility parameter, snails exposed to leaves and stems extracts of $L$. racemosa and $R$. mangle showed a flee behavior of solutions. Snails exposed to extracts of A. schaueriana showed normal motility. It is noted that the higher the concentration of solution, the more evident the flee behavior (Table 2).

Considering the cephalopodal mass status, snails exposed to leaves and stems extracts of A. schaueriana and $L$. racemosa, as well as leaves extract of $R$. mangle, showed normal status. Snails exposed to $R$. mangle stem extract were the only ones that showed expansion of their cephalopodal mass in all concentrations (Table 2).

Results on the mollusk feeding capacity are shown in Figure 1A. Extracts of plant parts showed significant differences in relation to feeding capacity $\left(\mathrm{F}_{2,48}\right)=8.9269$; $\mathrm{p}=0.00051$ ). Although $L$. racemosa has a greater effect on feeding, in general, the stem extract is the major responsible for this effect. There was a significant difference between the stems extracts of the three species, and the extract of A. schaueriana was the one that interfered the least with feeding. Regarding leaves extracts, the three species showed little influence on feeding.

Oviposition patterns of the snails exposed to extracts are shown in Figure 1B. Comparing the species, in general, there was a significant difference, and $L$. racemosa was the plant that presented the greatest interference on snails eggs posture $\left.\left(\mathrm{F}_{2,48}\right)=71.796, \mathrm{p}=0.00000\right)$, inhibiting up to $96.2 \%$ of this activity. When we considered the extracts origin (stems and leaves) we also observed that there was a difference in R. mangle $\left.\left(\mathrm{F}_{2,48}\right)=22.309 ; \mathrm{p}=0.00000\right)$, and the stem extract was more efficient than the leaves extract to inhibit mollusks oviposition reducing it in $65,4 \%$. A schaueriana was the species that interfered the least with oviposition (less than 1\%). We did not observe significant difference between extracts concentrations $(\mathrm{F}(4,45)=$ 0.21204; $\mathrm{p}=0.93041$ ).

\section{Extracts molluscicidal evaluation}

When comparing the molluscicidal effect among the three plant species, the snails mortality rate when exposed to $R$. mangle extracts was statistically higher than the mortality observed with A. schaueriana $\left(\chi^{2}=5.27, \mathrm{p}=0.0217\right)$, but there was no statistical difference between $R$. mangle and L. racemosa (Figure 2).

No significant difference was found between the plant parts (stems and leaves) of R. mangle, $\left(\chi^{2}=0.60\right.$, $\mathrm{p}=0.4384) ;$ A. schaueriana $\left(\chi^{2}=0.14, \mathrm{p}=0.7111\right)$ and L. racemosa $\left(\chi^{2}=2.88, \mathrm{p}=0.0897\right)$ in respect to the molluscicidal effect.

Analyzing the effect of the extracts concentrations of each plant, the following results were found: the effect of $R$. mangle extract on snail mortality shows a significant difference when the concentrations of $100 \mathrm{ppm}$ and $20 \mathrm{ppm}$ are compared $\left(\chi^{2}=8.44, \mathrm{p}=0.0037\right)$. No significant 
Table 2 - Motility and state of B. glabrata snails cephalopodal mass exposed to hydroalcoholic extracts of Avicennia schaueriana, Laguncularia racemosa and Rhizophora mangle

\begin{tabular}{|c|c|c|c|c|}
\hline Plant & Part & Concentration & Motility & Cephalopodal mass \\
\hline \multirow{8}{*}{ Avicennia schaueriana } & \multirow{4}{*}{ Leaves } & 100 ppm & Normal & Normal \\
\hline & & 60 ppm & Normal & Normal \\
\hline & & 20 ppm & Normal & Normal \\
\hline & & Control & Normal & Normal \\
\hline & \multirow{4}{*}{ Stem } & 100 ppm & Normal & Normal \\
\hline & & 60 ppm & Normal & Normal \\
\hline & & 20 ppm & Normal & Normal \\
\hline & & Control & Normal & Normal \\
\hline \multirow{8}{*}{ Laguncularia racemosa } & \multirow{4}{*}{ Leaves } & 100 ppm & 7 snails fleeing & Normal \\
\hline & & 60 ppm & 5 snails fleeing & Normal \\
\hline & & 20 ppm & 2 snails fleeing & Normal \\
\hline & & Control & 2 snails fleeing & Normal \\
\hline & \multirow{4}{*}{ Stem } & 100 ppm & 1 snail fleeing & Normal \\
\hline & & 60 ppm & 1 snail fleeing & Normal \\
\hline & & 20 ppm & Normal & Normal \\
\hline & & Control & 1 snail fleeing & Normal \\
\hline \multirow{8}{*}{ Rhizophora mangle } & \multirow{4}{*}{ Leaves } & 100 ppm & 5 snails fleeing & Normal \\
\hline & & 60 ppm & 2 snails fleeing & Normal \\
\hline & & 20 ppm & 1 snail fleeing & Normal \\
\hline & & Control & Normal & Normal \\
\hline & \multirow{4}{*}{ Stem } & 100 ppm & 7 snails fleeing & Expansion \\
\hline & & 60 ppm & 4 snails fleeing & Expansion \\
\hline & & 20 ppm & 1 snail fleeing & Expansion \\
\hline & & Control & 1 snail fleeing & Normal \\
\hline
\end{tabular}
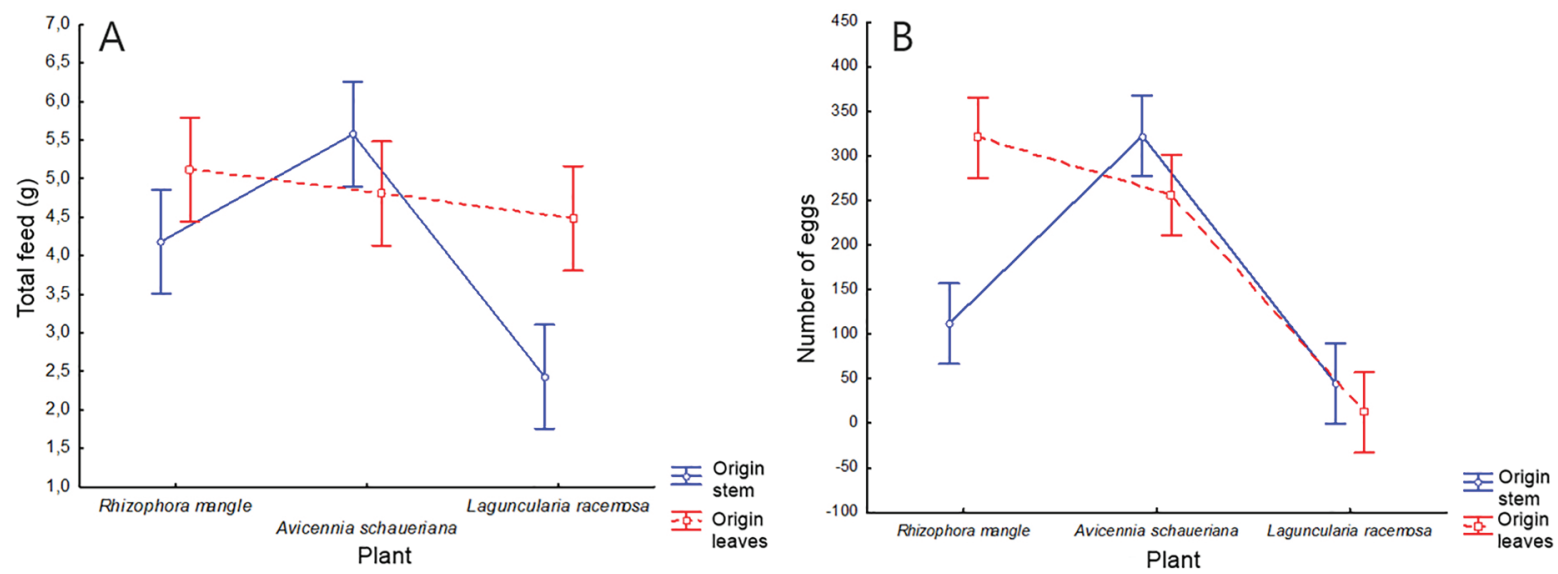

Figure 1 - A) Analysis of the interaction effect between the means of the total feeding capacity considering the mangrove species and the origin of extracts; B) Analysis of the interaction effect between the means of oviposition considering the mangrove species and the origin of extracts 


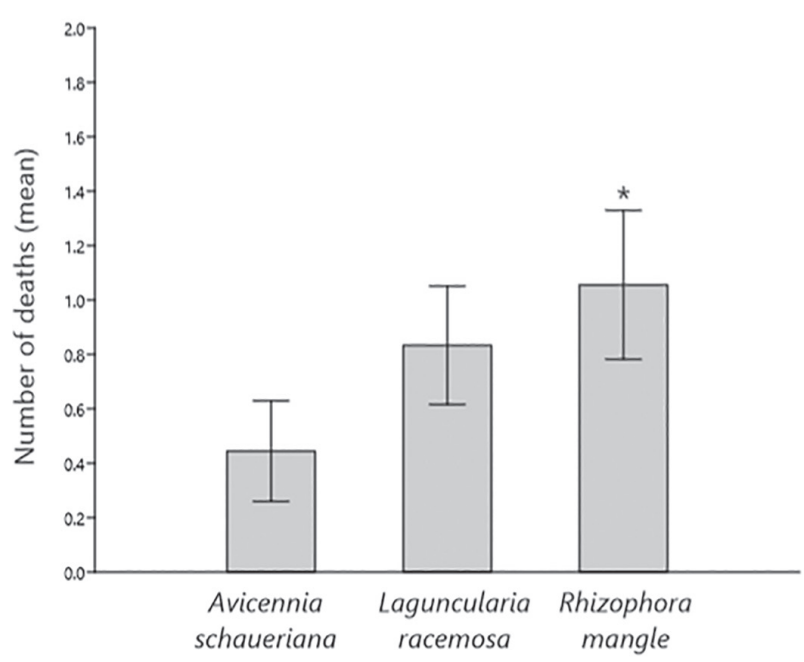

Figure 2 - Mortality of snails exposed to extracts by plant species. ${ }^{*} p<0.05$ when concentrations of 100 ppm and 20 ppm are compared.

difference was found between the extracts concentrations of A. schaueriana and L. racemosa on mollusk mortality $(\mathrm{p}>0.05)$.

\section{DISCUSSION}

The first records on the use of plants as molluscicides are in the pioneering study carried out by Archibald ${ }^{25}$, where it was shown that the fruits of the tree Balanites aegyptiaca possessed properties against Schistosomainfected mollusks, and the main active compound was a saponin. In a report entitled "Molluscicides in Schistosomiasis Control" by WHO, Mccullough et al. ${ }^{9}$ highlighted the considerable reduction in the incidence and prevalence of Schistosoma mansoni in Adwa, Northeast Ethiopia, as a result of efforts to control mollusks through the application of a molluscicide from Phytolacca dodecandra for five years.

In Brazil, the pioneer studies with plants that showed molluscicidal activity were those performed with Sejania sp. L. (cipó-timbó) and Sapindus saponaria L. (saboneteira) on B. glabrata ${ }^{26}$. Mendes et al. ${ }^{27}$ also studied the molluscicidal activity of 68 extracts from 23 Brazilian plants, and 22 of them were active on adult snails and 11 on eggs at a $100 \mathrm{ppm}$ concentration. Studies that have demonstrated the molluscicidal activity of plant extracts suggest that this effect is due to the presence of secondary metabolites such as tannins, saponins, terpenoids, steroids and flavonoids, among others ${ }^{10,28,29}$.

Tannins are considered nutritionally undesirable because they inhibit digestive enzymes and affect the use of vitamins and minerals. They are also known to act on microorganisms, since they have the property of easily complexing with metal ions, which act as enzymes cofactors for these organisms ${ }^{30}$. Complexation between tannins and proteins is essential both for control of insects, fungi and bacteria and for their pharmacological activities ${ }^{18} . R$. mangle, a highly taniferous species, presented antibacterial properties for Gram-positive and Gram-negative strains ${ }^{31}$ and antioxidant activity against induced gastric injury in rats ${ }^{32}$.

On the other hand, tannins also act as free radical captors, which cause several degenerative diseases such as cancer, multiple sclerosis, arteriosclerosis and the aging process itself. Therefore, these metabolites may have a double effect, given that at the same time they have a chemopreventive effect against cancer, they are possibly involved in the genesis of cancers, hepatotoxicity and antinutritional effects, as suggested by Chung et al. ${ }^{33}$.

During the evolutionary process, there is a loss of tannin concentrations in the Rosidae-Asteridae transition ${ }^{34}$. According to Godoy et al. ${ }^{19}$, L. racemosa and $R$. mangle (belonging to the subclass Rosidae) leaves present high tannin levels, while A. schaueriana (belonging to the subclass Asteridae) leaves provided extracts devoid of these metabolites, similarly to results achieved in the present study.

Another important compound is the saponin group, which has called great attention in recent years due to its varied biological properties. They can be classified into steroidal or triterpenic, depending on the nature of their aglycone part. Saponins have antimicrobial, antiinflammatory, antibiotic, antiplatelet, analgesic, antioxidant, hemolytic, hypoglycemic, anthelmintic, insecticidal, fungicidal, leishmanicidal and cytotoxic activities. This compound, when in contact with water, is characterized by abundant and persistent foam formation after agitation ${ }^{35,36}$. Leaves containing these metabolites are commonly used as natural detergents.

Some saponins may form complexes with cell membrane proteins and phospholipids. In mollusks, saponins act causing cell lysis (or hemolysis), resulting in release of lymph and consequently their death ${ }^{9,37}$. Thus, the major metabolite of interest in molluscicidal studies is saponin.

Considering the effect of extracts on the snails feeding capacity when exposed to extracts, there is a limited number of data analyzing this criterion. Pereira-Filho et $a l .{ }^{21}$ observed that the alimentary capacity of mollusks was totally suppressed when they were exposed to extract of $J$. gossypiifolia leaves. Lopes ${ }^{38}$ also verified mollusks feeding inhibition when in contact with Caryocar brasiliense leaves.

The effect of extracts on oviposition is another aspect to be considered in a molluscicidal assay. A study on the effects of $R$. mangle aqueous extracts, rich in tannins, on host snails of Fasciola hepatica, caused little effect on mortality. However, this extract interfered with mollusks 
oviposition. Whilst the concentration was increased, a smaller number of posts was obtained ${ }^{39}$. In a study on the effect of ethanolic extracts of $A$. muricata leaves and $J$. elliptica roots on B. glabrata embryos, the molluscicidal activity was present in all evaluated concentrations ${ }^{40}$.

Considering that B. glabrata snails are animals of easily reproduction, it is very important to use extracts of plants with oviposition inhibitory effect, so that these products can be considered as a tool to control these animals ${ }^{41}$.

Contreras $^{39}$ observed that the aqueous extract of $R$. mangle leaves presented a low efficiency on Fasciola hepatica-transmitting snails, with a mortality of $6 \%$ in 24 $\mathrm{h}$ and $14 \%$ in $48 \mathrm{~h}$ after application.

Pereira-Filho et al..$^{21}$ in a study on the effect of Jatropha gossypiifolia leaves, obtained $100 \%$ of snails mortality at concentrations of 100 and $75 \mathrm{ppm}$ after $24 \mathrm{~h}$, and at concentrations of 50 and 25 ppm after $72 \mathrm{~h}$. Lopes ${ }^{38}$ verified a strong molluscicidal activity of $C$. brasiliense leaves extracts, obtaining $100 \%$ of B. glabrata mortality in $0.017 \mathrm{mg} / \mathrm{mL}$ after $24 \mathrm{~h}$. The hydroalcoholic extract of Syzygium jambolanum stems also caused $100 \%$ snails lethality at $125 \mathrm{ppm}$ concentration on the first day of exposure ${ }^{42}$.

Snails mortality is the main phenomenon sought when evaluating the molluscicidal potential of a plant extract. According to a 1983 WHO publication ${ }^{43}$, a plant extract should only be considered active when it achieves $90 \%$ mortality at concentrations of $20 \mathrm{ppm}$. Analyzing the results obtained in this work, it can be verified that Avicennia schaueriana, Laguncularia racemosa and Rhizophora mangle cannot be considered efficient molluscicidal plants.

Most studies with molluscicidal products from plants attribute their toxic effect to the presence of tannins and saponins. In the present study, however, we did not detect such a significant molluscicidal activity on the tested snails. These results are probably due to the low incidence of these metabolites in the species studied, except for $R$. mangle. The species Laguncularia racemosa, although presenting low amounts of tannins, has a higher concentration of saponins in relation to the other two studied species, and therefore was the one that most interfered in the biological activities such as feeding and oviposition. On the other hand, Avicennia schaueriana, devoid of these metabolites, had the least interference with biological activities and snails mortality. Rhizophora mangle, which presented low amounts of saponins, but a high concentration of tannins, showed an intermediate toxic effect when compared to the other studied species in relation to its effect on the biological activities of $B$. glabrata snails.

We conclude that the present study has demonstrated the importance of the presence of saponins and tannins in sufficient quantities in the studied plants extracts so that they can interfere with the biological activities of mollusks. Although the three studied species have a low molluscicidal potential in relation to the parameters required by WHO, Rhizophora mangle and Laguncularia racemosa can be used as a biological tool in the control of these animals proliferation.

\section{CONFLICT OF INTERESTS}

All authors have none to declare.

\section{ACKNOWLEDGMENTS}

We wish to thank the Núcleo de Imunologia Básica e Aplicada of Universidade Federal do Maranhão, the Fundação de Amparo à Pesquisa do Estado do Maranhão (FAPEMA), and the Herbário do Maranhão for the support in the identification and cataloguing of species.

\section{AUTHORS' CONTRIBUTIONS}

Renato Juvino, Aline Nogueira, Karla Araújo, Clícia Rosane, Adalberto Pereira Filho, Iramar Barbosa and Natale Silva contributed to plant samples collection, extracts preparation, phytochemical tests, mollusks collection, laboratory maintenance and performance of molluscicides tests. Alexandre Azevedo contributed to statistical analyses. The trainees' students of the Herbário do Maranhão contributed with identification, cataloguing and deposit of the vegetal specimens collected. Ivone Garros Rosa contributed with the study design, laboratory supervision and experiments and with the writing of the article.

\section{REFERENCES}

1. Raso G, Vounatsou P, McManus DP, N'Goran EK, Utzinger JA. A Bayesian approach to estimate the age-specific prevalence of Schistosoma mansoni and implications for schistosomiasis control. Int J Parasitol. 2007;37:1491-500.

2. Ribeiro KA, de Carvalho CM, Molina MT, Lima EP, LópezMontero E, Reys JR, et al. Activities of naphthoquinones against Aedes aegypti (Linnaeus, 1762) (Diptera: Culicidae), vector of dengue and Biomphalaria glabrata (Say, 1818), intermediate host of Schistosoma mansoni. Acta Trop. 2009;111:44-50.

3. World Health Organization. Schistosomiasis: fact sheet. Geneva: WHO; 2017. [cited 2017 Jul 26]. Available from: http://www. who.int/mediacentre/factsheets/fs115/en/ 
4. Brasil. Ministério da Saúde. Situação epidemiológica: dados Brasília: Ministério da Saúde; 2017. [cited 2017 Jul 26]. Available from: http://portalsaude.saude.gov.br/index.php/oministerio/principal/leia-mais-o-ministerio/656-secretariasvs/vigilancia-de-a-a-z/esquistossomose/11244-situacaoepidemiologica-dados.

5. Miranda GS, Miranda BS, Rodrigues JG, Lira MG, Nogueira RA, Silva-Souza N, et al. The wild water-rats and their relevance in the context of schistosomiasis mansoni in Brazil: what we know and recommendations for further research. Helminthologia. 2017;54:1-5.

6. Carvalho OS, Coelho PM, Lenzi HL. Epidemiologia e controle da esquitossomose mansoni. In: Carvalho OS, Coelho PM, Lenzi HL, organizadores. Schistosoma mansoni \& esquistossomose: uma visão multidisciplinar. Rio de Janeiro: Fiocruz; 2008. p. 965-1008.

7. World Health Organization. Division of Vector Biology and Control. Data sheet on pesticides n ${ }^{\circ}$ 63: niclosamide. Geneva: WHO; 1988.

8. Marston A, Hostettmann K. Plant molluscicides. Phytochemistry. 1985;24:639-52.

9. McCullough FS, Gayral P, Duncan J, Christie JD. Molluscicides in schistosomiasis control. Bull World Health Organ. 1980;58:681-9.

10. Cantanhede SP, Marques AM, Silva-Souza N, Valverde AL. Atividade moluscicida de plantas: uma alternativa profilática Rev Bras Farmacogn. 2010;20:282-8.

11. Vasconcellos MC, Santos JAA, Silva IP, Lopes FEF, Schall VT. Molluscicidal activity of crown of Christ (Euphorbia splendens var. hislopii) (Euphorbiaceae) latex submitted to $\mathrm{pH}$ variation. Braz Arch Biol Technol. 2003;46:415-20.

12. Adewunmi CO. Natural products as agents of schistosomiasis control in Nigeria: a review of progress. Int J Crude Drug Res. 1984;22:161-6

13. Wills RB, Bone K, Morgan M. Herbal products: active constituents modes of action and quality control. Nutr Res Rev. 2000;13:4777.

14. Verpoorte R. Pharmacognosy in the new millennium: leadfinding and biotechnology. J Pharm Pharmacol. 2000;52:253-62.

15. Simões CM, Schenkel EP, Grosmann G, organizadores. Farmacognosia: da planta ao medicamento. $5^{\mathrm{a}}$ ed. Porto Alegre: Editora da UFRGS: Florianópolis: Editora da UFSC; 2004

16. Salunkhe DK, Chavan JK, Kadam SS. Dietary tannins: consequences and remedies. Boca Raton: CRC; 1990.

17. Naczk M, Nichols T, Pink D, Sosulski F. Condensed tannins in canola hulls. J Agric Food Chem. 1994;42:2196-200.

18. Santos SC, Mello JC. Taninos. In: Simões CM, Schenkel EP, Gosmann G, Mello JC, Mentz LA, Petrovick PR, organizadores. Farmacognosia: da planta ao medicamento. $6^{\text {a }}$ ed. Porto Alegre: Editora da UFRGS: Florianópolis: Editora da UFSC; 2007. p. 615-56.
19. Godoy SA, Mayworm MA, Lo VK, Salatino A, Schaeffer-Novelli Y. Teores de ligninas, nitrogênio e taninos em folhas de espécies típicas do mangue. Rev Bras Bot. 1997;20:35-40.

20. Matos FJ. Introdução à fitoquímica experimental. $3^{\mathrm{a}}$ ed. Fortaleza: Editora da UFC; 2009.

21. Pereira Filho AA, França CR, Oliveira DS, Mendes RJ, Gonçalves JR, Rosa IG. Evaluation of the molluscicidal potential of hydroalcoholic extracts of Jatropha gossypiifolia Linnaeus, 1753 on Biomphalaria glabrata (Say, 1818). Rev Inst Med Trop Sao Paulo. 2014;56:505-10.

22. Brasil. Ministério da Saúde. Secretaria de Vigilância em Saúde. Vigilância e controle de moluscos de importância epidemiológica: diretrizes técnicas: Programa de Controle da Esquistossomose (PCE). $2^{\mathrm{a}}$ ed. Brasília: Ministério da Saúde; 2008.

23. Smithers SR, Terry RJ. The immunology of schistosomiasis. Adv Parasitol. 1976;14:399-424.

24. World Health Organization. Molluscicide screening and evaluation. Bull World Health Organ. 1965;33:567-81.

25. Archibald RG. The use of the fruit of the tree Balanites aegyptiaca in the control of schistosomiasis in the Sudan. Trans R Soc Trop Med. 1933;27:207-10.

26. Pinto C, Almeida AF. Um novo método para a profilaxia da esquistossomose mansoni. Mem Inst Oswaldo Cruz. 1944;40:291-311.

27. Mendes NM, Pereira JP, Souza CP, Oliveira ML. Ensaios preliminares em laboratório para verificar a ação moluscicida de algumas espécies da flora brasileira. Rev Saude Publica. 1984;18:348-54.

28. Mandefro B, Mereta ST, Tariku Y, Ambelu A. Molluscicidal effect of Achyranthes aspera L. (Amaranthaceae) aqueous extract on adult snails of Biomphalaria pfeifferi and Lymnaea natalensis. Infect Dis Poverty 2017;6:133.

29. Yang C, Zhang M, Lei B, Gong G, Yue G, Chang X, et al. Active saponins from root of Pueraria peduncularis (Grah. ex Benth.) Benth. and their molluscicidal effects on Pomacea canaliculata. Pest Manag Sci. 2017;73:1143-7.

30. Monteiro JM, Albuquerque UP, Araújo EL, Amorim EL. Taninos: uma abordagem da química à ecologia. Quim Nova. 2005;28:892-6.

31. Ferreira FS, Santos SC, Barros TF, Rossi-Alva JC, Fernandez LG. Atividade antibacteriana in vitro de extratos de Rhizophora mangle L. Rev Bras Plantas Med. 2011;13:305-10.

32. de-Faria FM, Almeida AC, Luiz-Ferreira AL, Takayama C, Dunder RJ, Silva MA, et al. Antioxidant action of mangrove polyphenols against gastric damage induced by absolute ethanol and ischemia-reperfusion in the rat. Sci World J. 2012:2012:327071

33. Chung KT, Wong TY, Wei CI, Huang Y, Lin YW. Tannins and human health: a review. Crit Rev Food Sci Nutr. 1998;38:42164. 
34. Gardner RO. Systematic distribution and ecological function of the secondary metabolites of the Rosidae-Asteridae. Biochem Syst Ecol. 1977;5:29-35.

35. Bandaranayake WM. Bioactivities, bioactive compounds and chemical constituents of mangrove plants. Wetl Ecol Manag. 2002;10:421-52.

36. Santos FM, Simões JC, Silva JR, Barthus RC, Poppi RJ, Amaral AC. Otimização das condições de extração de saponinas em Ampelozizyphus amazonicus usando planejamento experimental e metodologia de superfície de resposta. Quim Nova. 2011;34:1629-33.

37. Schenkel EP, Gosmann G, Athayde ML. Saponinas. In: Simões CM, Schenkel EP, Gosmann G, Mello JC, Mentz LA, Petrovick PR, organizadores. Farmacognosia: da planta ao medicamento. $6^{\text {a }}$ ed. Porto Alegre: Editora da UFRGS: Florianópolis: Editora da UFSC; 2007. p. 711-40.

38. Lopes TC, Gonçalves JR, Souza NS, Moraes DF, Amaral FM, Rosa IG. Avaliação moluscicida e perfil fitoquímico das folhas de Caryocar brasiliense Camb. Cad Pesq. 2011;18:23-30.
39. Contreras JC. Eficiencia del extracto acuoso de Rhizophora mangle sobre Lymnaea (Fossaria) cubensis, hospedeiro intermediario de Fasciola hepatica em condiciones de campo. Kuxulkab' Rev Divulg. 2009;15:45-50.

40. Rocha TJ, Nascimento Filho BP, Noé BD, Veiga Júnior CP, Costa GN, Aragão MB, et al. Estudo do efeito moluscicida de espécies vegetais em embriões e caramujos adultos de Biomphalaria glabrata Say, 1818 (Gastropoda, Planorbidae). Rev Patol Trop. 2013;42:230-9.

41. Tang SS, Whitfield PJ, Perret S. Activity of the molluscicidal plant Milletia thonningii (Leguminosae) toward Biomphalaria glabrata eggs. J Parasit. 1995;81:833-5.

42. Lobato LF, Lopes TC, Lima HS, Cruz VC, Silva NR, Peixoto $\mathrm{CR}$, et al. Influência de Syzygium jambolanum na fertilidade de Biomphalaria glabrata. Rev Hosp Univ UFMA. 2007;8:86.

43. World Health Organization. Report of the Scientific Working Group on Plant. Geneva: WHO; 1983 [cited 2017 Jul 26]. Available from: http://apps.who.int/iris/bitstream/10665/60086/1/ TDR_SCH-SWG_4_83.3_eng.pdf 